\title{
OPTIMIZATION OF SYNTHESIS PARAMETERS FOR LEAD OXIDE NANOPARTICLES USING RESPONSE SURFACE METHODOLOGY
}

\author{
1İsmail Kutlugün AKBAY, ${ }^{2 *}$ Ahmet GÜNGÖR, ${ }^{3}$ Rükan GENÇ, ${ }^{4}$ Tonguç ÖZDEMİR \\ 1,2,4 Department of Chemical Engineering, Mersin University, Mersin, Turkey, \\ ${ }^{3}$ Advanced Technology Research and Application Center, Mersin University, 33343, Mersin, Turkey \\ 1akbay@mersin.edu.tr, 2ahmet.gungor@mersin.edu.tr, ${ }^{3}$ rukangnc@gmail.com, \\ 4tonguc.ozdemir@gmail.com
}

(Geliş/Received: 25.09.2018; Kabul/Accepted in Revised Form: 11.12.2018)

\begin{abstract}
Nano-sized lead oxide has useful applications that can be used in industry. In this study, the synthesis parameters were optimized using response surface methodology and ANOVA study was also carried out. Reaction temperature, sodium hydroxide and lead (II) acetate concentration were studied as the factors and the particle size was selected as the response variable. The modification was lead to increase the adequate precision of the model. Close results between $\mathrm{R}^{2}$ (correlation coefficient) and $\mathrm{R}^{2}$ adj showed the accuracy of the model. The optimum results of the study were found $14.89 \mathrm{M}$ $\mathrm{NaOH}$ concentration, $0.87 \mathrm{M} \mathrm{Pb}$ (II)Ac and reaction temperature of $88.56^{\circ} \mathrm{C}$. The particle size of lead II oxide was found to be $19.75 \mathrm{~nm}$ under optimum parameters.
\end{abstract}

Key Words: Central Composite Design, Lead Oxide, Nanoparticle, Optimization, RSM

\section{Yüzey Cevap Metodolojisi Kullanilarak Kurşun Oksit Nanoparçaciklarinin Sentez Parametrelerinin Optimizasyonu}

ÖZ: Nano boyutlu kurşun oksit, endüstride kullanılabilecek faydalı uygulamalara sahiptir. Bu çalışmada, sentez parametreleri cevap yüzey metodolojisi kullanılarak optimize edilmiş ve ANOVA çalışması da yapılmıştır. Sentez parametreleri olarak reaksiyon sıcaklığı, sodyum hidroksit ve kurşun (II) asetat konsantrasyonu incelenmiştir ve parçacık boyutu cevap değişkeni olarak seçilmiştir. Optimizasyon sonucunda modelin hassasiyeti artmıştır. $\mathrm{R}^{2}$ (korelasyon katsayısı) ile $\mathrm{R}^{2}$ adj arasındaki yakın sonuç, modelin doğruluğunu göstermiştir. Çalışmanın sonucunda, $14.89 \mathrm{M} \mathrm{NaOH}$ konsantrasyonu, $0.87 \mathrm{M} \mathrm{Pb}$ (II)Ac konsantrasyonu ve $88.56^{\circ} \mathrm{C}$ reaksiyon sicaklı̆̆ koşulları olarak belirlenmiştir. Kurşun (II) oksidin parçacık büyüklüğü, optimum parametreler altında $19.75 \mathrm{~nm}$ olarak bulunmuştur.

Anahtar Kelimeler: Merkezi Kompozit Dizayn, Kurşun Oksit, Nanoparçacık, Optimizasyon, RSM

\section{INTRODUCTION}

Nanoparticles have enchanted properties such as low density, high surface to volume ratio and quantum properties. There is a growing interest in developing nano-sized particles of different materials. Up until, there are different synthesis methods for nanoparticle synthesis such as; electrolysis, sonochemical synthesis, co-precipitation, hydrothermal, thermal decomposition and spray pyrolysis. Even with these methods, the particle size control could be the main problem for maintaining small diameters and narrow size distribution(Li et al. 2015; Weng et al. 2014; Xing et al. 2015).

To solve this problem, optimization methods could be benefited. One of the easiest and powerful methods is response surface methodology (RSM). RSM, a mathematical approach for finding the 
optimum conditions for a system, is widely used for optimization (Akbay, Güngör, and Özdemir 2017; Cho and Zoh 2007).RSM is one of most useful the design of experiments method that used to calculate the values for the unknown function approximately with fewer input values. The one at a time method for optimization is bothersome and time-consuming, whereas, the RSM allows the reduction in the experimental trials and has automated designing system according to the variables(Körbahti and Taşyürek 2015; Raissi and Farsani 2009).

As it is well known, lead is used in various areas for many applications. Lead oxide has different crystalline forms such as $\mathrm{PbO}, \mathrm{PbO}_{2}$, and etc. In particular, $\mathrm{PbO}$ has two different crystalline forms namely, litharge $(\alpha-\mathrm{PbO})$ and massicot $(\beta-\mathrm{PbO})$. The nano-sized lead oxide is attracting the attention of researchers for many decades. Battery, sensor, active layers, radiation shielding are the main usage areas of lead oxide(Hassan Karami, Karimi, and Haghdar 2008; Wilkinson et al. 2001).

There are several studies regarding the synthesis of nanoparticles with obtained parameters with different methods whereas there is no literature on the optimization of Lead Oxide synthesis with the RSM method. Vaidyanathan et al. (2010) studied silver nanoparticle synthesis parameters by optimization. They optimized the enzymatic activity on particle size. The particles synthesized were in the range from 10 to $80 \mathrm{~nm}$. Even with optimization, particle size distribution was not sufficient (Vaidyanathan et al. 2010). Ba-Abbad et al. (2015) studied the nano-sized nickel oxide optimization using Box-Behnken design. The process parameters were selected as molar ratio, solution $\mathrm{pH}$ and calcination temperature. The particle size for optimized parameters was found to be $14 \mathrm{~nm}$ (Ba-Abbad et al. 2015). Sun et al. studied optimization and modeling of $\mathrm{TiO}_{2}$ nanoparticles coated on hollow glass microspheres. The experimental parameters were chosen as calcination temperature, titanium butoxide amount and template F127. The synthesized particles were used for degradation efficiency of methyl orange (Sun et al. 2014). Ba-Abbad et al. studied the optimization of $\mathrm{ZnO}$ nanoparticles synthesized with minimal size using D-optimal design. The optimum conditions were reported as molar ratio of 1.76, $\mathrm{pH}$ of 1.5 and calcination temperature of $402{ }^{\circ} \mathrm{C}$ (Ba-Abbad et al. 2013).

In this study, the parameters of nano-sized lead oxide synthesis were examined and the optimum parameters were found via $\mathrm{RSM}$. The $\mathrm{NaOH}$ and $\mathrm{Pb}(\mathrm{II}) \mathrm{Ac}$ concentration and reaction temperature were selected as independent variables for optimization parameters. ANOVA and regression studies were also carried out. The optimized parameters were tested experimentally. The particle size obtained from experimental study were similar with the optimization study.

\section{EXPERIMENTAL}

Central composite design (CCD), used for the RSM for optimization, is a strong experimental and statistical way for designing experiments parameters. CCD with three conditions at three values for one response (particle size) was coded between the -1 and +1 using Stat-Ease Design Expert 10.0 ${ }^{\mathrm{TM}}$ (Akbay, Güngör, and Özdemir 2017). The three conditions for optimization software were, $\mathrm{NaOH}$ concentration, (10, 14.5 and $19 \mathrm{M}) ; \mathrm{Pb}$ (II)Ac concentration (0.8, 1.0 and $1.2 \mathrm{M})$ and reaction temperature, $\left(80,90,100{ }^{\circ} \mathrm{C}\right)$. Design parameters are given in Table 1.

Table 1. Experimental design for the study

\begin{tabular}{|c|c|c|c|c|}
\hline Code & Experimental parameters & $\mathbf{- 1}$ & $\mathbf{0}$ & $\mathbf{+ 1}$ \\
\hline $\mathrm{A}$ & $\mathrm{NaOH}$ Concentration $(\mathrm{mol} / \mathrm{L})$ & 10 & 14.5 & 19 \\
\hline $\mathrm{B}$ & $\mathrm{Pb}(\mathrm{II})$ Ac Concentration $(\mathrm{mol} / \mathrm{L})$ & 0.8 & 1.0 & 1.2 \\
\hline $\mathrm{C}$ & Reaction Temperature $\left({ }^{\circ} \mathrm{C}\right)$ & 80 & 90 & 100 \\
\hline
\end{tabular}

To determine variation between the conditions and the response, analysis of variables (ANOVA) were done. " $\mathrm{F}$ ", " $\mathrm{R}$ (correlation coefficient)" and " $\mathrm{p}$ " values were used to determine the significance of the model and the fitting of the model to the experimental results (Akbay, Güngör, and Özdemir 2017; Cho and Zoh 2007).

Lead (II) acetate trihydrate $\left(\mathrm{Pb}\left(\mathrm{C}_{2} \mathrm{H}_{3} \mathrm{O}_{2}\right)_{2} * 3 \mathrm{H}_{2} \mathrm{O}\right)$ powder $(99.99 \%)$, sodium hydroxide $(\mathrm{NaOH})(98 \%)$ and $25 \%$ aqueous solution of acetic acid $\left(\mathrm{CH}_{3} \mathrm{COOH}\right)(99 \%)$ were obtained from Sigma-Aldrich. All chemicals 
were used as received.

The aqueous solution of lead(II) acetate trihydrate was heated to constant temperature. The heated solution was added directly in aqueous $\mathrm{NaOH}$ solution under high rpm stirring. The mixture was stirred until obtaining a red colored solution. The precipitate was filtered with a Buchner funnel and washed with deionized water several times. The washed particles were frozen at $-80^{\circ} \mathrm{C}$ for a night. The frozen particles were dried in a freeze dryer (INNOVA mark INOFD-10 model) thorough lyophilization. The characterization of the particles was described in another study of our research group (Güngör, Genç, and Özdemir 2017).

The size of nanoparticles was measured with Zetasizer Nano ZS from Malvern with a detector angle of $173^{\circ}$. The particles size was calculated 3 times. The $10 \%(\mathrm{v}: \mathrm{v})$ acetic acid solution was used as a solvent.

\section{RESULTS AND DISCUSSION}

\section{ANOVA Results}

ANOVA for Response Surface Reduced Fifth model results and model equation are shown in Table 2. The optimal model for the study was selected as modified to surface reduced fifth model. Values of "Prob $>F^{\prime}$ " less than 0.05 indicate that model terms are significant, while the values greater than 0.1 indicate that the model terms are not significant (Körbahti and Taşyürek 2015). To maintain the hierarchical order, the not significant parameters were also added to the optimization model. It was seen that $\mathrm{Pb}(\mathrm{II}) \mathrm{Ac}$ concentration and reaction temperature were significant, whereas $\mathrm{NaOH}$ concentration was not significant due to high p-value. $\mathrm{p}$-values for all conditions model are given in Table 2, which show that the models were significant because there was only a $0.01 \%$ change. This $0.01 \%$ change could occur due to noise(Dehghani et al. 2017; Yaghmaeian et al. 2016). 
Table 2. ANOVA for Response Surface Reduced Fifth model and equation of the model

\begin{tabular}{|c|c|c|c|c|c|c|}
\hline Source & $\begin{array}{l}\text { Sum of } \\
\text { Squares }\end{array}$ & $\begin{array}{l}\text { Mean } \\
\text { Square }\end{array}$ & $\begin{array}{c}\text { Coefficient } \\
\text { Estimate }\end{array}$ & $\begin{array}{l}\text { Standard } \\
\text { Error }\end{array}$ & F Value & p-value \\
\hline Model & 10733.56 & 596.31 & 26.09 & 3.65 & 24.93 & $<0.0001$ \\
\hline $\mathrm{A}-\mathrm{NaOH}$ & 7.03 & 7.03 & -1.87 & 3.46 & 0.29 & 0.6024 \\
\hline $\mathrm{B}-\mathrm{Pb}-\mathrm{Ac}$ & 710.90 & 710.90 & 6.28 & 1.15 & 29.73 & 0.0006 \\
\hline C-T & 402.39 & 402.39 & 10.57 & 2.58 & 16.83 & 0.0034 \\
\hline $\mathrm{AB}$ & 49.29 & 49.29 & 2.03 & 1.41 & 2.06 & 0.1890 \\
\hline $\mathrm{AC}$ & 119.84 & 119.84 & 5.47 & 2.45 & 5.01 & 0.0556 \\
\hline $\mathrm{BC}$ & 2269.58 & 2269.58 & 13.75 & 1.41 & 94.90 & $<0.0001$ \\
\hline $\mathrm{A}^{2}$ & 787.25 & 787.25 & 19.84 & 3.46 & 32.92 & 0.0004 \\
\hline $\mathrm{B}^{2}$ & 38.46 & 38.46 & -4.39 & 3.46 & 1.61 & 0.2404 \\
\hline $\mathrm{C}^{2}$ & 63.69 & 63.69 & 7.29 & 4.46 & 2.66 & 0.1413 \\
\hline $\mathrm{ABC}$ & 464.36 & 464.36 & 7.62 & 1.73 & 19.42 & 0.0023 \\
\hline $\mathrm{A}^{2} \mathrm{C}$ & 1.20 & 1.20 & 0.55 & 2.45 & 0.050 & 0.8285 \\
\hline $\mathrm{AB}^{2}$ & 224.73 & 224.73 & -12.98 & 4.24 & 9.40 & 0.0155 \\
\hline $\mathrm{AC}^{2}$ & 4.91 & 4.91 & 1.92 & 4.24 & 0.21 & 0.6625 \\
\hline $\mathrm{B}^{2} \mathrm{C}$ & 12.55 & 12.55 & -1.77 & 2.45 & 0.52 & 0.4894 \\
\hline $\mathrm{A}^{2} \mathrm{C}^{2}$ & 342.67 & 342.67 & -16.03 & 4.24 & 14.33 & 0.0053 \\
\hline $\mathrm{AB}^{2} \mathrm{C}$ & 287.89 & 287.89 & 10.39 & 2.99 & 12.04 & 0.0084 \\
\hline $\mathrm{B}^{2} \mathrm{C}^{2}$ & 390.32 & 390.32 & 17.11 & 4.24 & 16.32 & 0.0037 \\
\hline $\mathrm{AB}^{2} \mathrm{C}^{2}$ & 407.26 & 407.26 & 21.40 & 5.19 & 17.03 & 0.0033 \\
\hline \multicolumn{7}{|c|}{$\begin{array}{l}\text { Particle Size }=26.09+-1.86 * A+6.28 * B+10.57 * C+2.026^{*} A B+5.47^{*} A C+13.75 * B C+ \\
19.84 * A^{2}+-4.39 * B^{2}+7.29 * C^{2}+7.62 * A B C+0.55 * A^{2} C+-12.98 * A^{2}+1.92 * A C^{2}+- \\
1.77 * B^{2} C+-16.03 * A^{2} C^{2}+10.39 * A B^{2} C+17.11 * B^{2} C^{2}+21.40 * A^{2} C^{2}\end{array}$} \\
\hline
\end{tabular}

The regression coefficients of the suggested model are shown in Table 3. The similar regressions $\left(\mathrm{R}^{2}\right.$ (correlation coefficient) and $\mathrm{R}^{2}$ adj) shows that the model is convenient. The predicted regression coefficients values ( $R^{2}$ pred) are in close agreement with the adjusted regression coefficients values $\left(R^{2}\right.$ adj), that is because the difference between the two is less than 0.2 (Akbay, Güngör, and Özdemir 2017). For appropriate optimization models, an adequate precision ratio greater than 4 is desirable. The adequate precision ratio is given in Table 3, and it is much higher than 4, which indicates the accuracy of the model. Figure 1 shows that the predicted and actual values of the model are similar and this proved the accuracy of the model developed. The close results for different parameters show the accuracy of the optimization study.

Table 3. Regression values of the optimization study

\begin{tabular}{|c|c|}
\hline R-Squared & 0.9825 \\
\hline Adj R-Squared & 0.9431 \\
\hline Pred R-Squared & 0.7433 \\
\hline Adeq Precision & 23.852 \\
\hline
\end{tabular}




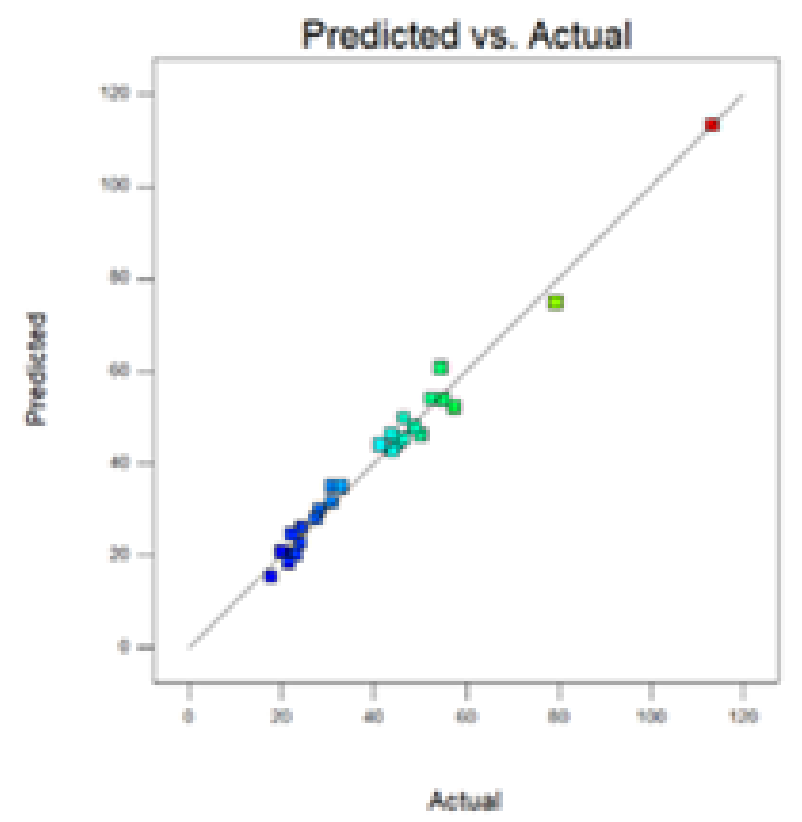

Figure 1. Predicted and Actual values for the optimization study

\section{Optimization Results}

In order to have a controllable final particle size, optimization studies were conducted by changing important experimental parameters that are known to be effective in particle growth. For this purpose, the optimization study consists of $\mathrm{NaOH}$ concentration, $\mathrm{Pb}(\mathrm{II}) \mathrm{Ac}$ concentration and reaction temperature were examined via RSM. The experimental design and the observed responses are given in Table 4. 
Table 4. Experimental design and observed responses

\begin{tabular}{|c|c|c|c|}
\hline $\mathrm{NaOH}$ Concentration & $\mathrm{Pb}$ (II)Ac Concentration & Temperature & Particle Size \\
\hline $\mathrm{mol} / \mathrm{L}$ & $\mathrm{mol} / \mathrm{L}$ & ${ }^{\circ} \mathrm{C}$ & $\mathrm{nm}$ \\
\hline 14.50 & 1.00 & 80.00 & 24.011 \\
\hline 19.00 & 0.80 & 80.00 & 43.82 \\
\hline 19.00 & 0.80 & 90.00 & 21.57 \\
\hline 14.50 & 1.00 & 90.00 & 24.3 \\
\hline 19.00 & 1.20 & 80.00 & 23.11 \\
\hline 14.50 & 1.20 & 80.00 & 28.16 \\
\hline 10.00 & 1.20 & 90.00 & 54.49 \\
\hline 10.00 & 1.00 & 100.00 & 44.04 \\
\hline 10.00 & 0.80 & 90.00 & 57.42 \\
\hline 19.00 & 1.20 & 90.00 & 30.91 \\
\hline 19.00 & 1.00 & 100.00 & 55.075 \\
\hline 14.50 & 1.20 & 100.00 & 79.32 \\
\hline 14.50 & 0.80 & 90.00 & 17.72 \\
\hline 14.50 & 1.00 & 100.00 & 41.44 \\
\hline 10.00 & 1.00 & 90.00 & 48.7 \\
\hline 10.00 & 1.00 & 80.00 & 30.89 \\
\hline 19.00 & 1.00 & 90.00 & 44.95 \\
\hline 14.50 & 1.20 & 90.00 & 27.48 \\
\hline 10.00 & 0.80 & 100.00 & 22.26 \\
\hline 10.00 & 1.20 & 100.00 & 46.34 \\
\hline 19.00 & 1.00 & 80.00 & 20.031 \\
\hline 14.50 & 0.80 & 80.00 & 45.23 \\
\hline 10.00 & 1.20 & 80.00 & 50.13 \\
\hline 19.00 & 1.20 & 100.00 & 113.25 \\
\hline 19.00 & 0.80 & 100.00 & 52.67 \\
\hline 10.00 & 0.80 & 80.00 & 46.39 \\
\hline 14.50 & 0.80 & 100.00 & 32.99 \\
\hline
\end{tabular}

Figure 2 shows the effects of $\mathrm{NaOH}$ and $\mathrm{Pb}$ (II)Ac concentration on particle size. High concentration of $\mathrm{NaOH}$ and low concentration of $\mathrm{Pb}$ (II)Ac leads to smaller particle size. Higher concentration of $\mathrm{NaOH}$ tends to grow smaller particles due to the higher nucleation rate(Jyoti, Vijay, and Radha 2013). When the $\mathrm{Pb}$ (II)Ac concentration increased, a fast accumulation over the seeds occurs and results with agglomeration which leads to larger particles. Therefore, a lower concentration of $\mathrm{Pb}(\mathrm{II}) \mathrm{Ac}$ gives better results. 


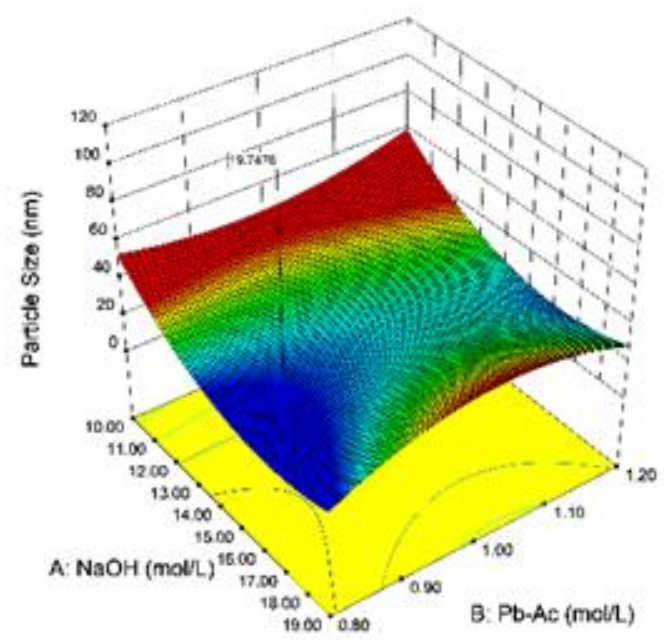

Figure 2. The effects of $\mathrm{NaOH}$ and $\mathrm{Pb}(\mathrm{II}) \mathrm{Ac}$ concentration on the particle size of lead oxide nanoparticles

Figure 3 shows the effects of $\mathrm{NaOH}$ concentration and reaction temperature on particle size. As it is obvious that the medium concentration of $\mathrm{NaOH}$ leads best results. As it is well-known that, the reaction rate is increased with high temperatures. However, as the reaction temperature exceeds $90{ }^{\circ} \mathrm{C}$, agglomeration occurs due to the increased reaction rates. Moreover, the reaction medium, water, starts to boil at higher temperatures. However, due to the water, which is the reaction medium in this study, reaches the boiling temperature for higher temperatures.

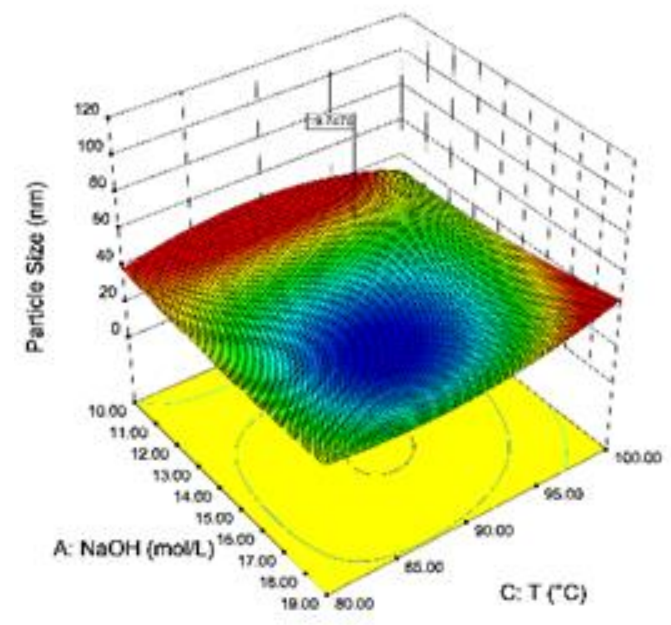

Figure 3. The effects of $\mathrm{NaOH}$ concentration and reaction temperature on the particle size of lead oxide nanoparticles

Figure 4 shows the effects of $\mathrm{Pb}$ (II)Ac concentration and reaction temperature on particle size It is clear that, the reaction rate is increased with high temperatures. Unfortunately, as it was observed, higher reaction temperature caused agglomeration that leads to bigger particles. For $\mathrm{Pb}$ (II)Ac concentration case, with low $\mathrm{Pb}(\mathrm{II}) \mathrm{Ac}$ concentration, available precursor number per reducer has increased and this leads to smaller particle sizes (Genç et al. 2011). 


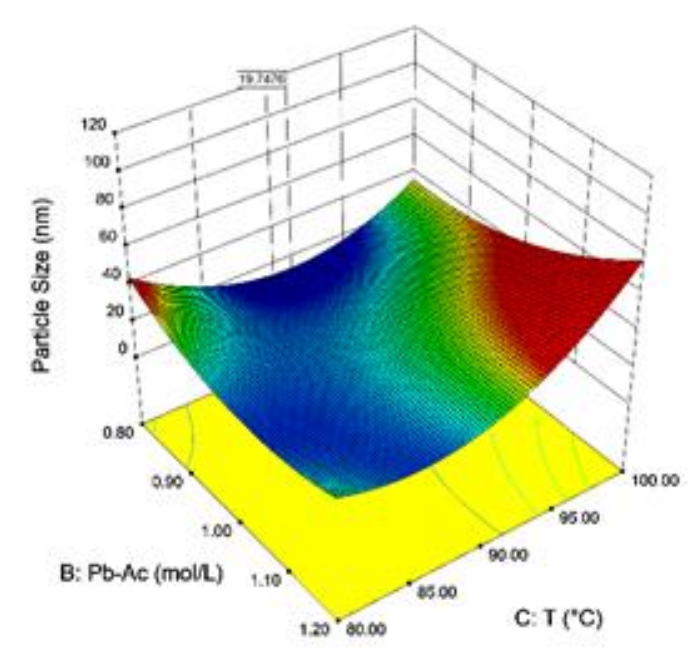

Figure 4. The effects of $\mathrm{Pb}(\mathrm{II}) \mathrm{Ac}$ concentration and reaction temperature on the particle size of lead oxide nanoparticles

Optimization test results are given in Table 5. With the optimization study, we managed to decrease the reaction temperatures while achieving smaller particles. In addition, the usage of $\mathrm{NaOH}$ amount was decreased. The optimization study resulted with a $19.75 \mathrm{~nm}$ particle size.

Table 5. Optimization results of Lead (II) oxide nanoparticle size

\begin{tabular}{|c|c|c|}
\hline Factor & Factor & Optimum \\
\hline $\mathrm{A}$ & $\mathrm{NaOH}(\mathrm{M})$ & 14.89 \\
\hline $\mathrm{B}$ & $\mathrm{Pb}(\mathrm{II}) \mathrm{Ac}(\mathrm{M})$ & 0.87 \\
\hline $\mathrm{C}$ & $\mathrm{T}\left({ }^{\circ} \mathrm{C}\right)$ & 88.56 \\
\hline \multicolumn{2}{|c|}{ Optimum Result } & $19.75 \mathrm{~nm}$ \\
\hline
\end{tabular}

\section{Experimental testing of the Optimized parameters}

Theoretical calculations could sometimes be misleading without an experimental test. To prove the optimum test parameters, a test was carried out with the optimum parameters. To improve the accuracy of the calculations, the DLS test were done quartet. Size distribution of particles under optimum parameters are given in Figure 5. As it is seen from Figure 5, the particles size is about about $20 \mathrm{~nm}$. Additionally, size distributions of particles are given in Table 5. Table 6 shows that mean particle size is $22.26 \mathrm{~nm}$. The majority of the particle size distribution is under $32 \mathrm{~nm}$. The optimization study leads to a narrow size distribution. The obtained results are in line with the RSM test and it proves the accuracy and precision of the optimization study that was carried out.

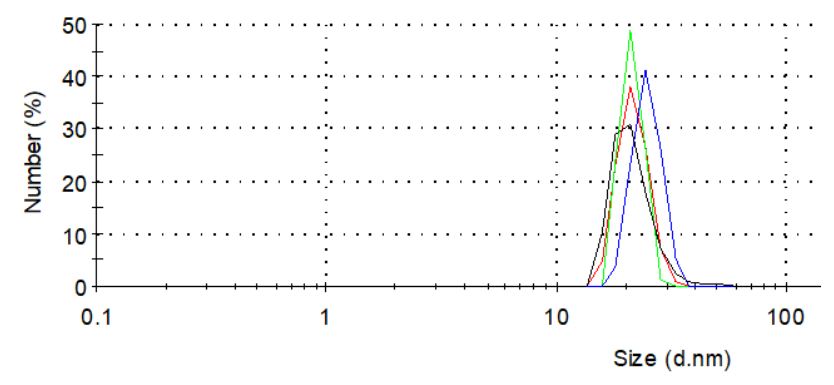

Figure 5. Size distribution of particle size under optimum parameters. 
Table 6. Size distribution of particles

\begin{tabular}{|c|c|}
\hline Particle Size (nm) & \% Percent \\
\hline 15.69 & 3.7 \\
\hline 18.17 & 19.8 \\
\hline 21.04 & 35.4 \\
\hline 24.36 & 27.9 \\
\hline 28.21 & 10.5 \\
\hline 32.67 & 2 \\
\hline 37.84 & 0.2 \\
\hline 43.82 & 0.1 \\
\hline 50.75 & 0.1 \\
\hline 58.77 & 0.1 \\
\hline Mean Particle Size & $\mathbf{2 2 . 2 6}$ \\
\hline
\end{tabular}

So-called optimization methods such as "one-at-a-time" only find optimum results at the studied parameters. Similar results were obtained with broader size distribution for the study our group that conducted by our research group (Güngör, Genç, and Özdemir 2017). The advantage of our study is the well-defined reaction parameters such as reducing agent concentration and reaction temperature. Moreover, the obtained result is compared with the literature. This comparison has shown that our study has the smallest particle size and narrow distribution. The literature comparison is given in Table 7.

Table 7. Literature comparison based on the lead oxide particle size

\begin{tabular}{|c|c|c|c|}
\hline Group & Particle Size $\mathbf{( n m})$ & Method & Reference \\
\hline Karami et al. & 40 & Sonochemical & (Hasan Karami et al. 2008) \\
\hline Ranjbar et al. & 60 & Sonochemical & (Ranjbar and Morsali 2009) \\
\hline Wang et al. & 45 & Self-propagate & (Wang and Zhu 2012) \\
\hline Alagar et al. & 60 & Co-precipitation & (Alagar, Theivasant, and Raja 2012) \\
\hline Arulmozhi et al. & 30 & Chemical Synthesis & (Arulmozhi and Mythili 2013) \\
\hline Akbay et al. & 22 & Co-precipitation\&Lyophilization & Current study \\
\hline
\end{tabular}

The confidence interval for the RSM study is given in Table 7. For 95\% confidence interval, low and high values were found 12.84 and 26.65, respectively. The experimental result of $22.26 \mathrm{~nm}$ is between the \%95 confidence interval which proved the theoretical result via experimental results.

Table 7. Confidence interval for the test results

\begin{tabular}{|c|c|c|c|c|}
\hline Response & Optimum Result & Std Dev & 95\% CI low & 95\% CI high \\
\hline Particle Size & $19.75 \mathrm{~nm}$ & \pm 4.89 & $12.84 \mathrm{~nm}$ & $26.65 \mathrm{~nm}$ \\
\hline
\end{tabular}

\section{CONCLUSIONS}

Nanoparticles has many advantages over macro-sized particles such as, high surface area, quantum particle effects and so on. In this study, nano-sized lead (II) oxide synthesis parameters were optimized via RSM. The optimum results of the synthesis were found $14.89 \mathrm{M} \mathrm{NaOH}$ concentration, $0.87 \mathrm{M} \mathrm{Pb}$ (II)Ac and reaction temperature of $88.56{ }^{\circ} \mathrm{C}$. Under these optimum parameters, the particle size of lead II oxide was found to be $19.75 \mathrm{~nm}$. The results showed that higher reaction temperature caused agglomeration and higher $\mathrm{NaOH}$ and lower $\mathrm{Pb}(\mathrm{II}) \mathrm{Ac}$ concentration leads to higher precursor number per reducer, which resulted in lower particle size. ANOVA and regression test results with high $\mathrm{R}^{2}$ (correlation coefficient) values shown the accuracy of the model. Optimum parameters were tested experimentally and the obtained particle size were found as $22.26 \mathrm{~nm}$. Moreover, a narrow particle size distribution was obtained. These results were in line with $95 \%$ confidence interval obtained from RSM software. In summary, smaller 
particles with less sources were achieved using RSM. Obtained particles, which has small in diameter and narrow in distribution, could be find usage in photovoltaic, solar cells, electrochemical and catalytical applications.

\section{Nomenclature}

$\begin{array}{ll}\text { RSM } & : \text { Response Surface Methodology } \\ C C D & : \text { Central Composite Design } \\ P & : \text { Probability } \\ \text { ANOVA } & : \text { Analysis of Variances } \\ \text { Pred } & : \text { Predicted } \\ \text { Adj } & : \text { Adjusted }\end{array}$

\section{Conflict of Interest}

No conflict of interest was declared by the authors.

\section{REFERENCES}

Akbay, İsmail Kutlugün, Ahmet Güngör, and Tonguç Özdemir. 2017. “Optimization of the Vulcanization Parameters for Ethylene-propylene-diene Termonomer (EPDM)/Ground Waste Tyre Composite Using Response Surface Methodology." Polymer Bulletin 74(12): 5095-5109.

Alagar, M., T. Theivasant, and A. Kubera Raja. 2012. "Chemical Synthesis of Nano-Sized Particles of Lead Oxide and Their Characterization Studies." Journal of Applied Sciences 12(4): 398-401. http://www.scialert.net/abstract/?doi=jas.2012.398.401 (June 11, 2018).

Arulmozhi, K. T., and N. Mythili. 2013. "Studies on the Chemical Synthesis and Characterization of Lead Oxide Nanoparticles with Different Organic Capping Agents." AIP Advances 3(12): 122122. http://aip.scitation.org/doi/10.1063/1.4858419 (June 11, 2018).

Ba-Abbad, Muneer M. et al. 2013. "Optimization of Process Parameters Using D-Optimal Design for Synthesis of $\mathrm{ZnO}$ Nanoparticles via Sol-Gel Technique." Journal of Industrial and Engineering Chemistry 19(1): 99-105. http://dx.doi.org/10.1016/j.jiec.2012.07.010.

- - - 2015. "Optimization of Nickel Oxide Nanoparticle Synthesis through the Sol-Gel Method Using Box-Behnken Design." Materials and Design 86: 948-56. http://dx.doi.org/10.1016/j.matdes.2015.07.176.

Cho, Il Hyoung, and Kyung Duk Zoh. 2007. "Photocatalytic Degradation of Azo Dye (Reactive Red 120) in TiO2/UV System: Optimization and Modeling Using a Response Surface Methodology (RSM) Based on the Central Composite Design." Dyes and Pigments 75(3): 533-43.

Dehghani, Mohammad Hadi, Maryam Faraji, Amir Mohammadi, and Hossein Kamani. 2017. "Optimization of Fluoride Adsorption onto Natural and Modified Pumice Using Response Surface Methodology: Isotherm, Kinetic and Thermodynamic Studies." Korean Journal of Chemical Engineering 34(2): 454-62. http://link.springer.com/10.1007/s11814-016-0274-4 (November 20, 2018).

Genç, Rükan, Gael Clergeaud, Mayreli Ortiz, and Ciara K. O'sullivan. 2011. "Green Synthesis of Gold Nanoparticles Using Glycerol-Incorporated Nanosized Liposomes." Langmuir 27(17): 10894-900.

Güngör, Ahmet, Rükan Genç, and Tonguç Özdemir. 2017. "Facile Synthesis of Semiconducting Nanosized 0D and 2D Lead Oxides Using a Modified Co-Precipitation Method." Journal of Turkish Chemical Society Part A: Chemistry 4(3): 1017-30.

Jyoti, Mayekar, Dhar Vijay, and Srinivasan Radha. 2013. "To Study the Role of Temperature and Sodium Hydroxide Concentration in the Synthesis of Zinc Oxide Nanoparticles." International Journal of 
Scientific and Research Publications 3(11): 2250-3153. www.ijsrp.org.

Karami, Hasan et al. 2008. "Synthesis of Lead Oxide Nanoparticles by Sonochemical Method and Its Application as Cathode and Anode of Lead-Acid Batteries." Materials Chemistry and Physics 108(23): 337-44. https://www.sciencedirect.com/science/article/pii/S0254058407006128\#bbib22 (June 11, 2018).

Karami, Hassan, Mohammad Ali Karimi, and Saeed Haghdar. 2008. "Synthesis of Uniform NanoStructured Lead Oxide by Sonochemical Method and Its Application as Cathode and Anode of Lead-Acid Batteries." Materials Research Bulletin 43(11): 3054-65.

Körbahti, Bahadır K., and Selin Taşyürek. 2015. “Electrochemical Oxidation of Ampicillin Antibiotic at Boron-Doped Diamond Electrodes and Process Optimization Using Response Surface Methodology." Environmental Science and Pollution Research 22(5): 3265-78. http://link.springer.com/10.1007/s11356-014-3101-7.

Li, Yuhan, Qi Qiang, Xingwang Zheng, and Zenglin Wang. 2015. "Controllable Electrochemical Synthesis of Ag Nanoparticles in Ionic Liquid Microemulsions." Electrochemistry Communications 58: 41-45. http://dx.doi.org/10.1016/j.elecom.2015.05.020.

Raissi, S, and R-Eslami Farsani. 2009. "Statistical Process Optimization through Multi-Response Surface Methodology." World Academy of Science, Engineering and Technology 51(46): 267-71.

Ranjbar, Zohreh Rashidi, and Ali Morsali. 2009. "Sonochemical Syntheses of a New Nano-Sized Porous Lead(II) Coordination Polymer as Precursor for Preparation of Lead(II) Oxide Nanoparticles." Journal of Molecular Structure 936(1-3): 206-12. https://www.sciencedirect.com/science/article/pii/S0022286009004992 (June 11, 2018).

Sun, Lei, Shungang Wan, Zebin Yu, and Lijun Wang. 2014. “Optimization and Modeling of Preparation Conditions of TiO2nanoparticles Coated on Hollow Glass Microspheres Using Response Surface Methodology." Separation and Purification Technology 125: 156-62. http://dx.doi.org/10.1016/j.seppur.2014.01.042.

Vaidyanathan, Ramanathan et al. 2010. "Enhanced Silver Nanoparticle Synthesis by Optimization of Nitrate Reductase Activity." Colloids and Surfaces B: Biointerfaces 75(1): 335-41.

Wang, Yu, and Jianxin Zhu. 2012. "Preparation of Lead Oxide Nanoparticles from Cathode-Ray Tube Funnel Glass by Self-Propagating Method." Journal of Hazardous Materials 215-216: 90-97. https://www.sciencedirect.com/science/article/pii/S0304389412001987 (June 11, 2018).

Weng, Ling et al. 2014. "Facile Fabrication and Properties of Core-Shell Structure Ag@Al2(SiO3)3nanocomposites with Controllable Morphologies." Materials Letters 126: 240-43. http://dx.doi.org/10.1016/j.matlet.2014.03.182.

Wilkinson, Tommy J. et al. 2001. "A Facile Wet Synthesis of Nanoparticles of Litharge, the Tetragonal Form of PbO." MRS Proceedings 704(Ii): 1-5.

Xing, Yan et al. 2015. "Controllable Synthesis and Characterization of Fe3O4/Au Composite Nanoparticles." Journal of Magnetism and Magnetic Materials 380(1): 150-56. http://dx.doi.org/10.1016/j.jmmm.2014.09.060.

Yaghmaeian, Kamyar, Susana Silva Martinez, Mohammad Hoseini, and Hoda Amiri. 2016. "Optimization of As(III) Removal in Hard Water by Electrocoagulation Using Central Composite Design with Response Surface Methodology." Desalination and Water Treatment: 1-7. http://www.tandfonline.com/doi/full/10.1080/19443994.2016.1177735 (November 20, 2018). 